\title{
A Familial Syndrome of Short Stature, Deformities of the Hands and Feet, and an Unusual Facies
}

\author{
ALAN E. H. EMERY and MATILDA M. NELSON \\ From the Department of Human Genetics, University of Edinburgh
}

The following is a report of a girl and her mother with short stature, deformities of the hands and feet, and an unusual facies which appears to be a unique syndrome.

\section{Case Report}

Sandra C. (H.G. No. 214.1) was the result of a fullterm normal delivery on 14 June 1946 . During the neonatal period she was noticed to be 'floppy', though subsequently her muscle tone gradually improved. She stood at 15 months, walked at 18 months, and began to talk at age 2 years. It was about this time that the deformities of her hands and feet were first noticed. Her childhood was uneventful though she was noted to be rather unresponsive and to be mentally backward. Menarche was at age 11, and her periods have been regular ever since. When 3 years old tonsillectomy was performed, and at 9 years of age she underwent operations to correct her foot deformities for which she had further manipulation at age 15 . Three years ago all her teeth were removed because of gross caries and pyorrhoea. Her general health has been good. She is at present employed on work of a routine nature by a firm of surgical instrument makers.

Clinical findings. She is $155 \mathrm{~cm}$. in height and weighs $43.6 \mathrm{~kg}$. The distal parts of her extremities are shorter than normal and her upper segment and lower segment measurements are $82.6 \mathrm{~cm}$. and $71.8 \mathrm{~cm}$., respectively. The upper segment to lower segment ratio is therefore 1.15 , the upper limit of normal for white females being about 0.96 (Eldridge, 1964). Her arm span is $139 \mathrm{~cm}$.

Her hands and feet are small. There are flexion deformities of the first three metacarpophalangeal joints, and extension deformities of the interphalangeal joints of both thumbs (Fig. 1). The proximal interphalangeal joints are slightly enlarged. All the toes are clawed (Fig. 2), particularly the hallux, and there is a mild degree of pes cavus (these deformities were considerably worse before operation).

Her facial appearance is unusual (Fig. 3). She has a high forehead, a depressed nasal bridge, a long philtrum

Received 3 April 1970. and the malar regions are flattened. Apart from some minimal weakness of the orbicularis oculi muscles, all the cranial nerves are intact. She has a high arched palate. Her ears are normal in size and shape. Her hair is dry and coarse. The skin of her hands and feet is somewhat thin and shiny but normal skin creases are present. Her nails are ridged but are otherwise normal.

Apart from the above findings and occasional extrasystoles, the results of clinical examination were normal. Her IQ is borderline defective: 76 (verbal scale), 81 (performance scale), and 77 (full scale).

Investigations. Except for the limb deformities evident on clinical examination, a skeletal $x$-ray survey revealed no other apparent abnormality. There were no lenticular opacities on slit-lamp examination. An electrocardiogram showed occasional ventricular extrasystoles but was otherwise normal. Serum phosphorus $(3.0 \mathrm{mg} . / 100 \mathrm{ml}$ ), calcium ( $4.9 \mathrm{~m} \mathrm{Eq} / 1$.$) , and alkaline$ phosphatase (27 I.U./1.) were normal as were the serum proteins, electrolytes, uric acid, urea, and glucose. The sheep cell agglutination test and ESR were normal, and the latex particle and Wassermann tests were negative. Her haemoglobin level was $11.6 \mathrm{~g} . / 100 \mathrm{ml}$. (79\%), but the red cell indices were normal. A blood film showed slight polychromasia. Quantitative amino acid chromatography of plasma and a 24-hour specimen of urine showed no abnormality and there was no excess of mucopolysaccharides in the urine. Chromosome studies on peripheral blood leucocytes showed a normal female karyotype.

\section{Family History}

The proband is illegitimate and her mother died of bronchopneumonia at age 26 . There is good evidence from close relatives and family photographs that the proband's mother was similarly affected, though no one else in the family appears to be affected (Fig. 4). According to relatives, the proband's mother was only about $152 \mathrm{~cm}$. tall and was very similar to the proband in appearance but quite different from all other members of the family including the maternal grandparents. She had the same facial appearance and it is difficult to distinguish photographs of the proband when she was a little girl, from those of her mother at the same age. 


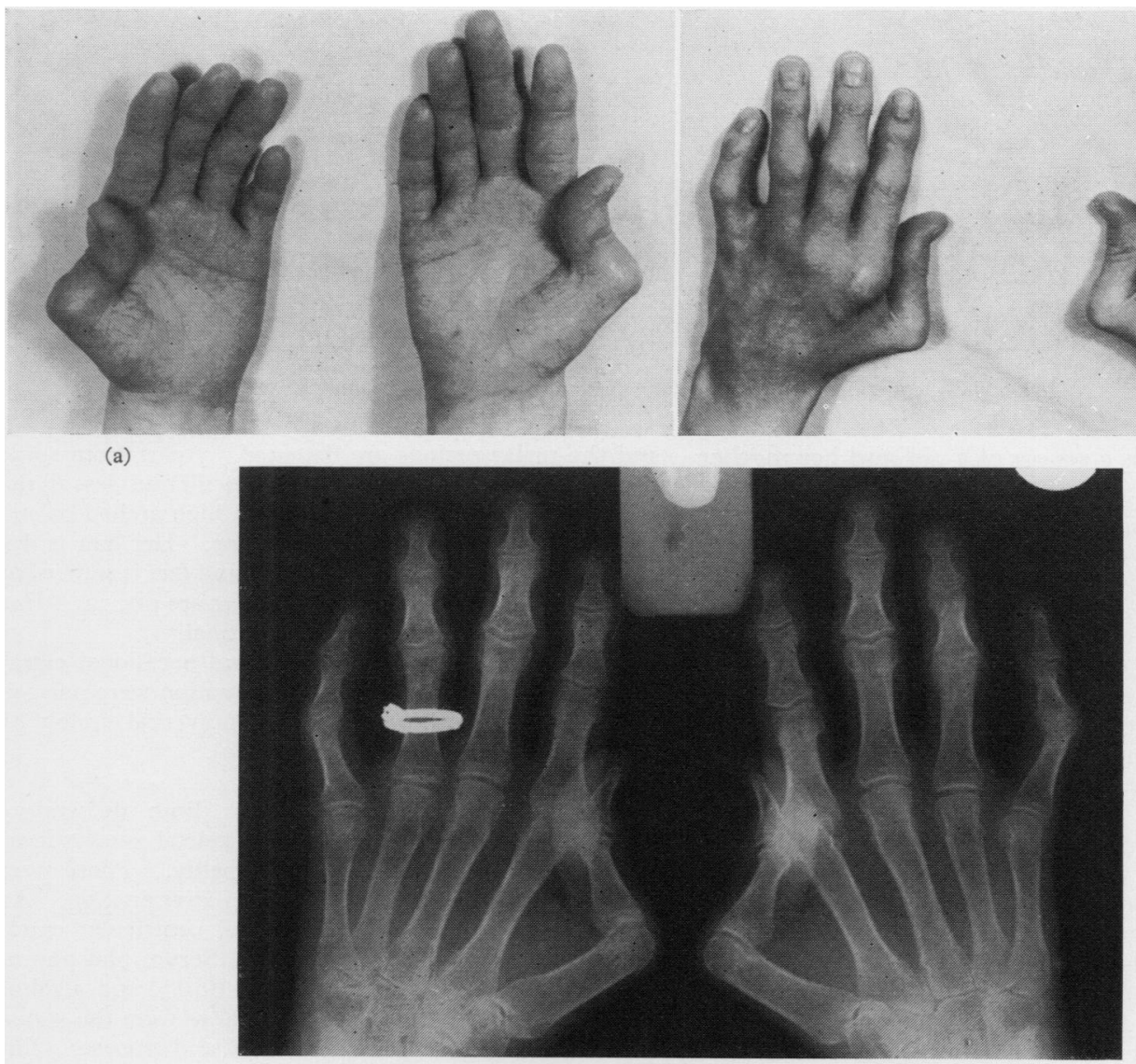

(c)

(b)

Fig. 1. Proband's hands.

Her mother also had short extremities, and her hands and feet were small and had the same deformities. However she was not mentally retarded. On the contrary, she was considered to be very intelligent by her relatives. In both the proband and her mother the deformities of the hands and feet were first noticed in early childhood, did not appear to get worse, and caused no discomfort.

\section{Discussion}

This syndrome of short stature, deformities of the hands and feet, and an unusual facies appears to be inherited as an autosomal dominant trait. The proband's mother was presumably the result of a new mutation.

TABLE

DIFFERENTIAL DIAGNOSIS OF FAMILIAL 'SHORT-LIMBED' DWARFISM

\begin{tabular}{|c|c|c|c|c|}
\hline Type & Inheritance & $\begin{array}{l}\text { Limb } \\
\text { Shortening }\end{array}$ & $\begin{array}{c}\text { Other Significant } \\
\text { Features }\end{array}$ & Reference \\
\hline $\begin{array}{l}\text { Achondroplasia } \\
\text { 'Metaphysial dysostosis' } \\
\text { (Schmid type) }\end{array}$ & $\begin{array}{l}\text { Autosomal dominant } \\
\text { Autosomal dominant }\end{array}$ & $\begin{array}{l}\text { Proximal } \\
\text { Proximal }\end{array}$ & $\begin{array}{l}\text { Abnormal skull } \\
\text { Normal skull }\end{array}$ & $\begin{array}{l}\text { Maroteaux and Lamy (1964) } \\
\text { Dent and Normand (1964) }\end{array}$ \\
\hline Spondyloepiphysial dysplasia & Autosomal dominant & Proximal & $\begin{array}{l}\text { Normal skull; abnormal } \\
\text { epiphyses }\end{array}$ & McKusick (1966) \\
\hline $\begin{array}{l}\text { Cartilage-hair hypoplasia } \\
\text { Diastrophic dwarfism }\end{array}$ & $\begin{array}{l}\text { Autosomal recessive } \\
\text { Autosomal recessive }\end{array}$ & $\begin{array}{l}\text { Proximal } \\
\text { Distal }\end{array}$ & $\begin{array}{l}\text { Sparse, fine hair } \\
\text { Clubbed hands and feet; } \\
\text { deformed ears }\end{array}$ & $\begin{array}{l}\text { Beals (1968) } \\
\text { Wilson, Chrispin, and Carter (1969) }\end{array}$ \\
\hline $\begin{array}{l}\text { Ellis-van Creveld syndrome } \\
\text { 'Metaphysial dysostosis' } \\
\text { (Spahr type) }\end{array}$ & $\begin{array}{l}\text { Autosomal recessive } \\
\text { Autosomal recessive }\end{array}$ & $\begin{array}{l}\text { Distal } \\
\text { Proximal }\end{array}$ & Polydactyly & $\begin{array}{l}\text { McKusick et al. (1964) } \\
\text { Spahr and Spahr-Hartmann (196I) }\end{array}$ \\
\hline Conradi's syndrome & Autosomal recessive & Proximal & $\begin{array}{l}\text { Stippled epiphyses, } \\
\text { cataracts }\end{array}$ & Comings, Papazian, and Schoene (1968) \\
\hline
\end{tabular}




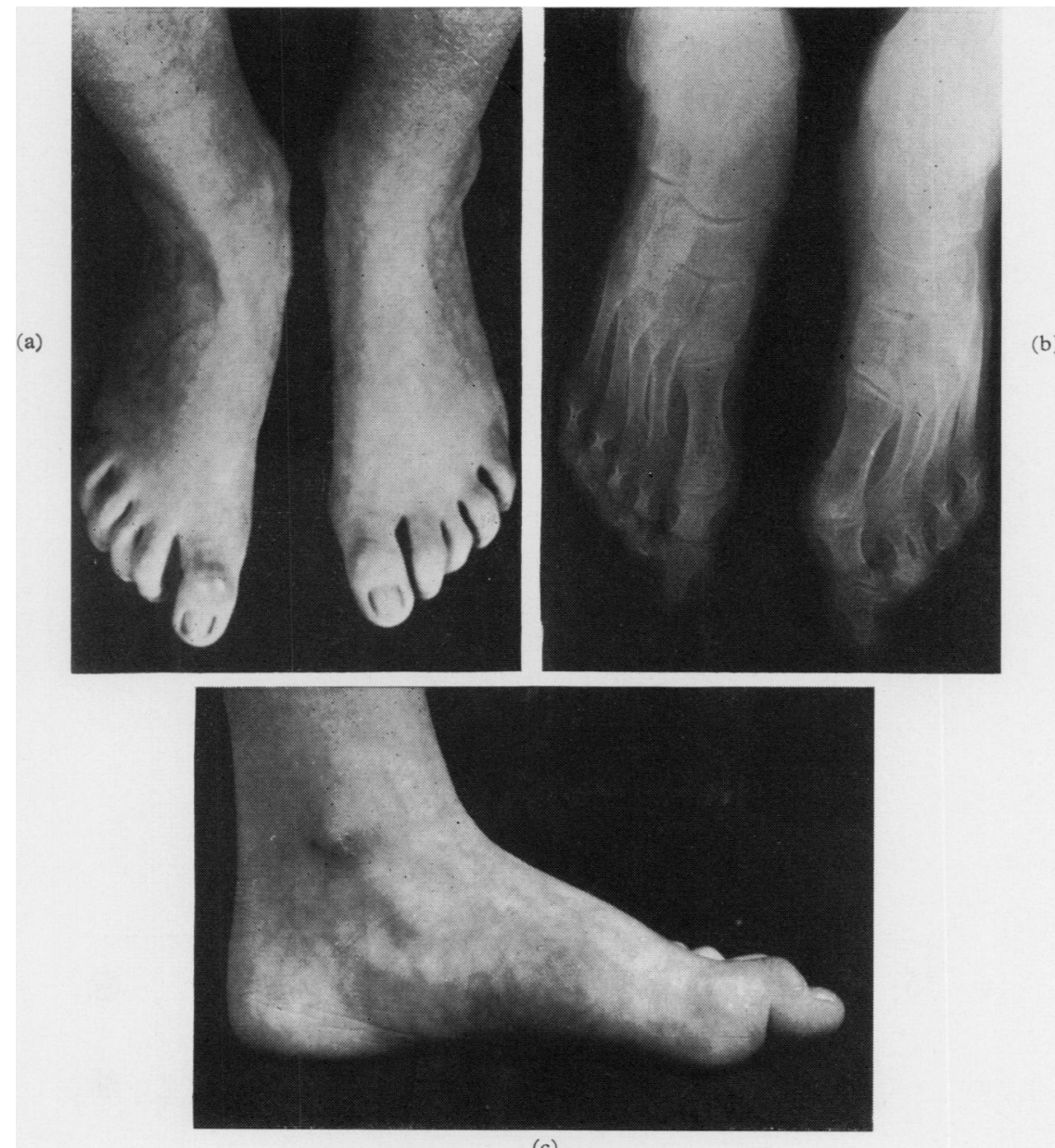

(c)

Fig. 2. Proband's feet.

In the differential diagnosis a number of syndromes associated with short limbs might be considered (Table). However, the characteristic clinical and radiographic features of each of these syndromes were not observed in the present case. These syndromes are also associated with relatively severe dwarfism, and though the proband has short stature this is not so conspicuous as to be considered a type of dwarfism.

Peripheral dysostosis (Garces et al., 1969), in which the hands and feet are small, is inherited as an autosomal dominant trait but is associated with particular $x$-ray changes which were not seen in the proband.

The deformities of the hands in the proband and her mother are sufficiently distinctive to be easily recognizable. The only other conditions in which it appears that somewhat similar deformities may occur are arthromyodysplasia congenita (Gorlin and Pindborg, 1964) and cranio-carpo-tarsal dysplasia (Weinstein and Gorlin, 1969). However other features of the former syndrome, such as involvement of larger joints, muscle hypoplasia, and multiple pterygia were not present in the proband. In the case of cranio-carpo-tarsal dysplasia, affected individuals also have an abnormally small mouth, characteristic 'whistling face' appearance, and particular facial $x$-ray changes, features that our patient did not have.

\section{Summary}

A girl and her mother are described with short stature, deformities of the hands and feet, and an unusual facies. This appears to be a unique syndrome. 


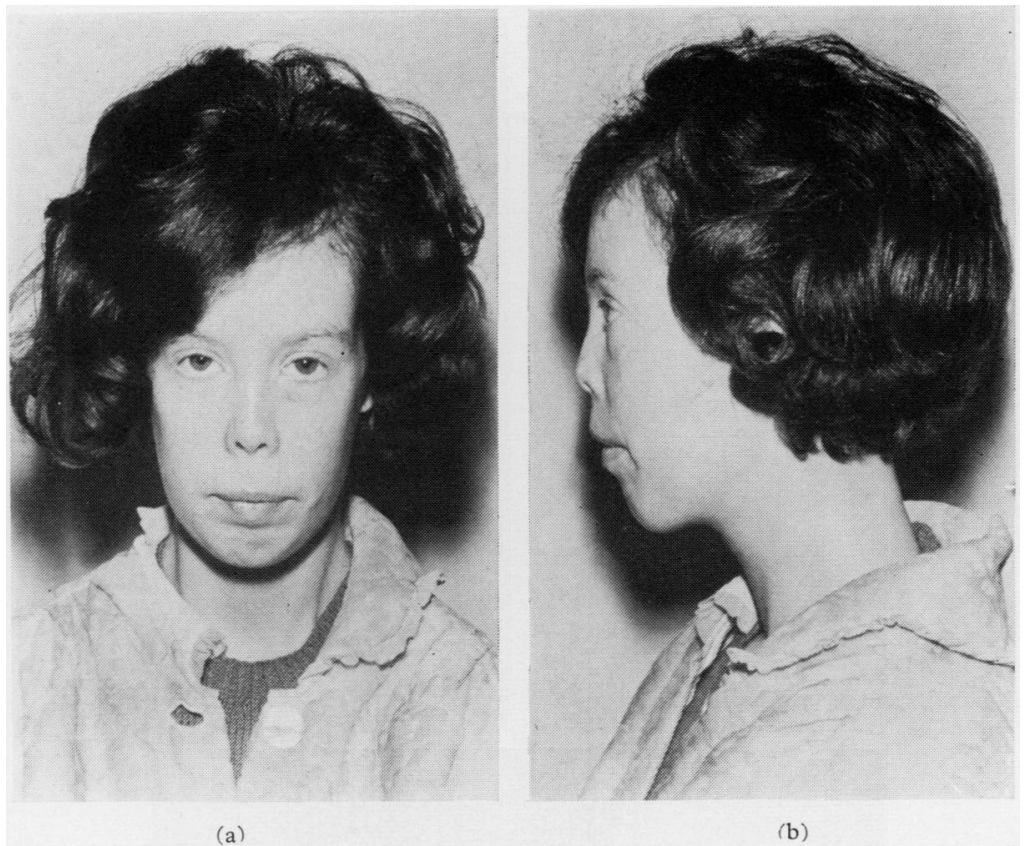

FIG. 3. Facial appearance.

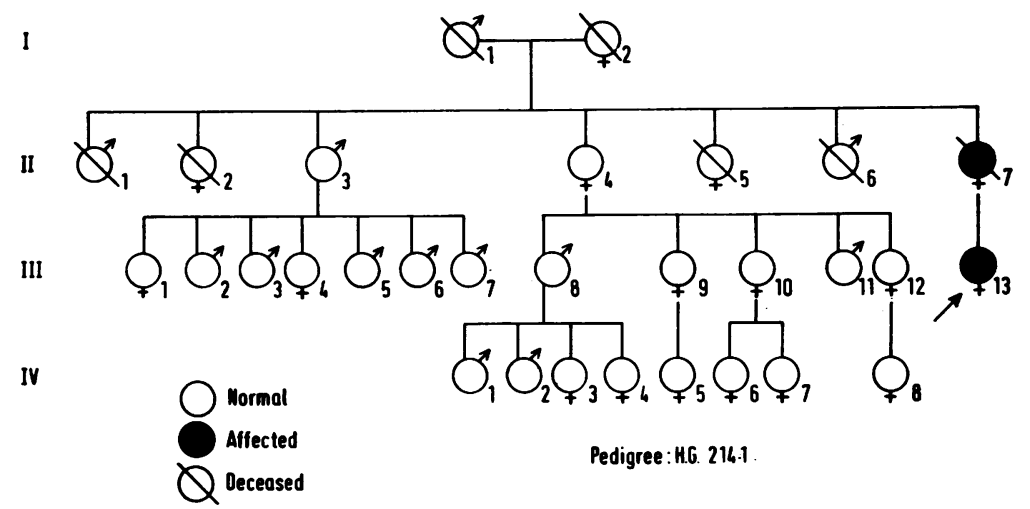

Fig. 4. Pedigree.

We should like to thank Dr. V. A. McKusick for his advice, and Dr. G. Komrower for the amino acid analysis of urine and plasma.

\section{REFERENCES}

Beals, R. K. (1968). Cartilage-hair-hypoplasia. A case report. fournal of Bone and foint Surgery, 50A, 1245-1249.

Comings, D. E., Papazian, C., and Schoene, H. R. (1968). Conradi's disease chondrodystrophia calcifans congenita, congenital stippled epiphyses. Fournal of Pediatrics, 72, 63-69.

Dent, C. E., and Normand, I. C. S. (1964). Metaphysial dysostosis, type Schmid. Archives of Disease in Childhood, 39, 444-454.

Eldridge, R. (1964). The metacarpal index. Archives of Internal Medicine, 113, 248-254.

Garces, L. Y., Blank, E., Drash, A. L., and Kenny, F. M. (1969). Peripheral dysostosis: investigation of metabolic and endocrine functions. Fournal of Pediatrics, 74, 730-737.
Gorlin, R. J., and Pindborg, J. J. (1964). Syndromes of the Head and Neck. McGraw-Hill, New York.

McKusick, V. A. (1966). Heritable Disorders of Connective Tissue, 3rd ed. Mosby, St. Louis.

, Egeland, J. A., Eldridge, R., and Krusen, D. E. (1964). Dwarfism in the Amish. I. Ellis-van Creveld syndrome. Bulletin of the fohns Hopkins Hospital, 115, 306-336.

Maroteaux, P., and Lamy, M. (1964). Achondroplasia in man and animals. Clinical Orthopaedics and Related Research, 33, 91-103.

Spahr, A., and Spahr-Hartmann, I. (1961). Dysostose métaphysaire familiale. Etude de 4 cas dans une fratrie. Helvetica Paediatrica Acta, 16, 836-849.

Weinstein, S., and Gorlin, R. J. (1969). Cranio-carpotarsal dysplasia or the whistling face syndrome. American Journal of Diseases of Children, 117, 427-433.

Wilson, D. W., Chrispin, A. R., and Carter, C. O. (1969). Diastrophic dwarfism. Archives of Disease in Childhood, 44, 48-58. 